Brazilian Journal

of Chemical

ISSN 0104-6632

Engineering

Printed in Brazil

Vol. 21, No. 02, pp. 147 - 153, April - June 2004

\title{
KINETIC MODEL FOR WHEY PROTEIN HYDROLYSIS BY ALCALASE MULTIPOINT- IMMOBILIZED ON AGAROSE GEL PARTICLES
}

\author{
R. Sousa Jr, G. P. Lopes, P. W. Tardioli, R. L. C. Giordano, \\ P. I. F. Almeida and R.C. Giordano* \\ Departamento de Engenharia Química, Universidade Federal de São Carlos, Fax: +(55-16) 260-8266, \\ Cx.P. 676, 13565-905, São Carlos, SP, Brazil. \\ E-mail: roberto@deq.ufscar.br
}

(Received: February 13, 2003 ; Accepted: October, 3, 2003)

\begin{abstract}
Partial hydrolysis of whey proteins by enzymes immobilized on an inert support can either change or evidence functional properties of the produced peptides, thereby increasing their applications. The hydrolysis of sweet cheese whey proteins by alcalase, which is multipoint-immobilized on agarose gel, is studied here. A MichaelisMenten model that takes into account competitive inhibition by the product was fitted to experimental data. The influence of $\mathrm{pH}$ on the kinetic parameters in the range 6.0 to 11.0 was assessed, at $50^{\circ} \mathrm{C}$. Initial reaction-rate assays in a pHstat at different concentrations of substrate were used to estimate kinetic and Michaelis-Menten parameters, $\mathrm{k}$ and $\mathrm{K}_{\mathrm{M}}$. Experimental data from long-term batch assays were used to quantify the inhibition parameter, $\mathrm{K}_{\mathrm{I}}$. The fitting of the model to the experimental data was accurate in the entire $\mathrm{pH}$ range.

Keywords: Enzymatic proteolysis, Michaelis-Menten kinetic model, competitive inhibition, whey hydrolysis.
\end{abstract}

\section{INTRODUCTION}

Cheese whey is a by-product of the dairy industry that for a long time has been considered a residue. However, its high BOD [35000 mg/l - compare, for example, with the $300 \mathrm{mg} / \mathrm{l} \mathrm{BOD}$ of domestic drains (Viotto, 1993)] and the high cost of its treatment have stimulated the search for commercial uses for it or its derivatives (Demetrakakes, 1997).

Partial hydrolysis of whey proteins can either change or evidence the functional properties of the peptides in this industrial residue, thereby increasing their applications. Hydrolyzed cheese whey can be a suitable protein source for infants and for individuals with a reduced digestive capacity. A tailor-made hydrolysis with specific enzymes, followed by convenient downstream processes, can also reduce phenylalanine contents in the product, which would thus be fitted to the diet of phenylketonuria patients.
Products containing bioactive peptides that are free of any bitterness can be obtained by partial hydrolysis of cheese whey proteins, making use of different proteases (Mann, 2000).

In general, the reaction rates of enzymatic proteolyses are assumed to follow either a MichaelisMenten or a first-order kinetics. First-order kinetics is the consequence of a mechanism where the ratecontrolling step is the first attack on the tertiary structure of the protein (Vorob'ev et al., 1996). The substrate and product concentrations in these rate equations are generally expressed either in terms of the number of hydrolyzable peptide bonds or of the degree of hydrolysis. It is also important to point out that competition for the active site between the original substrate and the peptides that are continuously produced during enzymatic proteolysis could bring about a substantial reduction in the reaction rates of hydrolysis.

*To whom correspondence should be addressed 
Making use of a pHstat, it is possible to observe the progress of the reaction by monitoring the consumption of a titrant, necessary to control the system $\mathrm{pH}$ during batch hydrolysis assays carried out in a laboratory-scale reactor.

This work focuses on the case of whey protein hydrolysis by alcalase, multipoint-immobilized on agarose gel particles. Initial reaction-rate assays in a pHstat, with different substrate concentrations and different $\mathrm{pH}$ 's made it possible to estimate the Michaelis-Menten kinetic parameters as a function of $\mathrm{pH}$. Long-term assays showed that a third additional parameter should be considered, that would take into account the inhibitory effect of the products. Data from long-term batch assays also permitted quantification of this additional parameter by the Marquardt algorithm (1963). Assays at $\mathrm{pH} 6,7,8,9,10$ and 11 were carried out. All assays were run at $50^{\circ} \mathrm{C}$, a temperature where high productivity is achieved without any significant loss of enzymatic activity (Lopes, 2001).

\section{ENZYMATIC PROTEOLYSIS}

In general, proteolytic reactions can be summarized as follows:

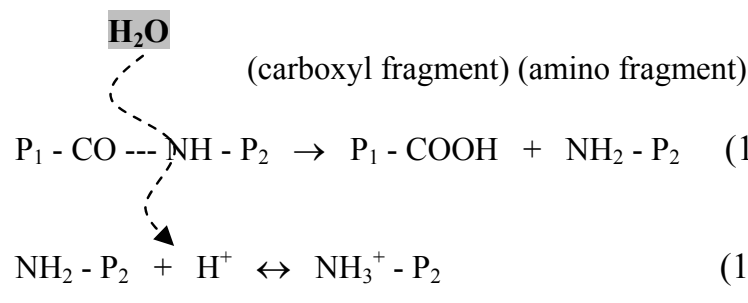

and

$\mathrm{P}_{1}-\mathrm{COOH} \leftrightarrow \mathrm{P}_{1}-\mathrm{COO}^{-}+\mathrm{H}^{+}$

According to Svendsen (1976) and Adler-Nissen (1986), it is generally accepted that serine proteases like alcalase, when acting on peptide bonds, follow Michaelis-Menten kinetics (see Equation 2, from Segel, 1975). Postolache and Oncescu (1989) also characterized the hydrolysis of casein and hemoglobin by alcalase according to MichaelisMenten kinetic models.

$$
\mathrm{V}=-\frac{\mathrm{k} \cdot \mathrm{E} \cdot \mathrm{N}}{\mathrm{K}_{\mathrm{M}}+\mathrm{N}}
$$

On the other hand, it could be expected that the original substrate and some of the peptides that are continuously released during the hydrolytic process would compete for the active site in the enzyme. Adler-Nissen (1986) and González-Tello et al. (1994) had already pondered the possibility of product inhibition. Equation 3 shows a Michaelis-Menten model with competitive inhibition (Segel, 1975).

$\mathrm{V}=-\frac{\mathrm{k} \cdot \mathrm{E} \cdot \mathrm{N}}{\mathrm{K}_{\mathrm{M}}\left(1+\frac{\mathrm{I}}{\mathrm{K}_{\mathrm{I}}}\right)+\mathrm{N}}$

where $\mathrm{N}$ is the molar concentration of peptide bonds in the substrate that can be hydrolyzed by alcalase, I is the molar concentration of the inhibitor and $\mathrm{k}, \mathrm{K}_{\mathrm{M}}$ and $\mathrm{K}_{\mathrm{I}}$ are the kinetic model parameters. Alcalase can hydrolyze about $25 \%$ of the total number of peptide bonds in the protein substrate.

When the pHstat technique is used, the consumption of base necessary for controlling system $\mathrm{pH}$ during the batch assay provides the degree of hydrolysis (DH) in a straightforward manner (Equation 4). The initial reaction rates can be determined from the base consumption during the initial minutes of each assay (Adler-Nissen, 1986).

$$
\mathrm{DH}=\frac{\mathrm{h}}{\mathrm{h}_{\text {tot }}} \times 100 \%=\mathrm{B} \times \mathrm{N}_{\mathrm{b}} \times \frac{1}{\alpha} \times \frac{1}{\mathrm{MP}} \times \frac{1}{\mathrm{~h}_{\text {tot }}} \times 100 \%
$$

where $\mathrm{h}_{\text {tot }}$ is the total number of peptide bonds in the protein substrate, in $\mathrm{meqv} / \mathrm{g}_{\text {protein }}$ (or simply $\mathrm{mmol} / \mathrm{g}_{\text {protein }}$ ); $\mathrm{h}$ is the number of hydrolyzed peptide bonds; $B$ is the base consumption in $\mathrm{ml} ; \mathrm{N}_{\mathrm{b}}$ is base normality; $\alpha$ is the average degree of dissociation of the $\alpha-\mathrm{NH}$ groups and MP is the mass of protein in $\mathrm{g}$.

Note that for the range of $\mathrm{pH}$ considered here, the carboxyl radical will be completely dissociated (reaction 1c will be displaced to the right). For this reason, the correction factor, $\alpha$, only considers the equilibrium of reaction $1 \mathrm{~b}$.

\section{MATERIALS AND METHODS}

Cooperativa de Lacticínios São Carlos donated in natura cheese whey, which was micro- (membrane A/G Technology Corporation $\left.{ }^{\circledR}, 0.45 \mu \mathrm{m}\right)$ and ultrafiltered (membrane Amicon ${ }^{\circledR}, 10000 \mathrm{Da}$ ) up to a concentration of $60 \mathrm{~g} / \mathrm{l}$.

The alcalase enzyme (Subtilisin) was multipointimmobilized on agarose gel particles (donated by Hispanagar, Spain). Based on Tardioli (2003), activated agarose gel (glioxyl agarose, $75 \mu \mathrm{mol} / \mathrm{ml}$ ) 
was suspended in bicarbonate buffer $50 \mathrm{mM}, \mathrm{pH} 10$ at a $1 / 10$ ratio $\left(\mathrm{V}_{\text {gel }} / \mathrm{V}_{\text {total }}\right)$. Then $100 \mu \mathrm{l}_{\text {alcalase }} / \mathrm{ml}_{\text {gel }}$ were added to the suspension and maintained under gentle shaking at $20{ }^{\circ} \mathrm{C}$ for 24 hours. Then 1 $\mathrm{mg}_{\text {sodiumborohidrete }} / \mathrm{ml}_{\text {suspension }}$ was added, maintaining the same stirring at $20{ }^{\circ} \mathrm{C}$ for 30 minutes. Finally, the reduced derivative was washed using distilled water in abundance.

In the jacketed reactor, coupled to the pHstat, the temperature of the concentrated cheese whey was raised to $50{ }^{\circ} \mathrm{C}$ and its $\mathrm{pH}$ adjusted by the manual addition of $\mathrm{HCl}$ and/or $\mathrm{NaOH}$. The immobilized enzymes were then quickly added to the reactor and the automatic $\mathrm{pH}$ control of the equipment switched on.

Initial-rate assays for different substrate concentrations and $\mathrm{pH}$ 's made it possible to estimate the parameters $\mathrm{k}$ and $\mathrm{K}_{\mathrm{M}}$ of the Michaelis-Menten kinetic model. Eighteen experiments lasting 15 minutes were carried out at $\mathrm{T}=50^{\circ} \mathrm{C}$. In each assay, $15 \mathrm{ml}$ of cheese whey $(20,40$ and $60 \mathrm{~g} / \mathrm{l})$ and $0.04 \mathrm{~g}$ of gel containing $15.7 \mathrm{U}_{\mathrm{BAEE}} / \mathrm{g}_{\text {gel }}$ were utilized. One UBAEE (of alcalase) hydrolyzes $1 \mu \mathrm{mol}$ of benzoil arginine ethylic ester per minute at $\mathrm{pH} 8$ and $25 \mathrm{oC}$. For each concentration, six $\mathrm{pH}$ values $(6,7,8,9,10$ and 11) were taken into account.

Four long-term hydrolysis experiments (lasting 5 hours) were also carried out, which made it possible to evaluate the adequacy of the pure MichaelisMenten model, and subsequently quantify the parameter $\mathrm{K}_{\mathrm{I}}$. In each assay, $30 \mathrm{ml}$ of cheese whey at $60 \mathrm{~g} / 1$ and $0.30 \mathrm{~g}$ of gel containing $13.4 \mathrm{U} \mathrm{BAEE} / \mathrm{g}_{\mathrm{gel}}$ were utilized. The assays were carried out at different $\mathrm{pH}: 7,8,9$ and $10\left(\mathrm{~T}=50^{\circ} \mathrm{C}\right)$.

Despite alcalase was immobilized on agarose gel particles, the vigorous stirring and high porosity of the gel substantially reduced convective and diffusive mass transport resistances. Therefore, we assumed that we were observing inherent reaction rates in our experimental conditions, i.e. free from mass transfer delays.

For $\mathrm{pH}$ control, $\mathrm{NaOH} 0.2 \mathrm{~N}$ or $0.5 \mathrm{~N}$ was utilized. For parameter $\alpha$, the values presented by Adler-Nissen were adopted (1986) (Table 1).

For cheese whey, $h_{\text {tot }}$ is $8.8 \mathrm{meqv} / \mathrm{g}_{\text {protein }}=8.8$ $\mathrm{mmol} / \mathrm{g}_{\text {protein }}$ (Adler-Nissen, 1986).

Table 1: Calibration values for the pHstat (Adler-Nissen, 1986).

\begin{tabular}{|c|c|}
\hline $\mathbf{p H}$ & $\mathbf{1} / \boldsymbol{\alpha}$ \\
\hline $\mathbf{1 1}$ & 1.00 \\
$\mathbf{1 0}$ & 1.00 \\
$\mathbf{9}$ & 1.01 \\
$\mathbf{8}$ & 1.13 \\
$\mathbf{7}$ & 2.27 \\
$\mathbf{6}$ & 13.6 (extrapolation) \\
\hline
\end{tabular}

\section{RESULTS AND DISCUSSION}

From the number of hydrolyzed peptide bonds per gram of gel calculated for the first minutes of reaction of the initial-rate assays, $\mathrm{hg}_{0} \times$ time curves, like the one shown in Figure 1, were built. Initial reaction rates $\left(\mathrm{V}_{0}\right)$ were obtained by linear regression.

Making use of the Lineweaver-Burk equation [Equation 5 (Segel, 1975)], $\mathrm{k}$ and $\mathrm{K}_{\mathrm{M}}$ were estimated, as shown in Figure 2.

$-\frac{1}{\mathrm{~V}_{0}}=\frac{\mathrm{K}_{\mathrm{M}}}{\mathrm{k} \cdot \mathrm{E}} \cdot \frac{1}{\mathrm{~N}}+\frac{1}{\mathrm{k} \cdot \mathrm{E}}$

The results are presented in Table 2. Figures 3 and 4 show them graphically. The point corresponding to $\mathrm{pH} 7$ (an outlier) was discarded. It is important to note that assays with finely crushed gel particles indicated the absence of diffusion resistance effects, The experimental effectiveness factor $\eta$ was always essentially equal to unity, for the gel enzymatic load used here.

The curves in Figures 3 and 4 are typical results (activity and $\mathrm{K}_{\mathrm{M}}$ vs. $\mathrm{pH}$ ).

The model was validated against long-term batch assays. Without the inhibition term, the predicted reaction rates were noticeably higher than the experimental. Figure 5 shows the model predictions and the experimental values for the number of peptide bonds hydrolyzed by the enzyme $\left(\mathrm{N}_{0}-\mathrm{N}\right.$ in $\mathrm{mmol} / \mathrm{l}_{\text {solution }}$ with $\mathrm{N}_{0}=8.8 \times 60 \times 0.25=132 \mathrm{mmol} / /_{\text {solution }}$ ), for one of the five-hour assays in the pHstat. 


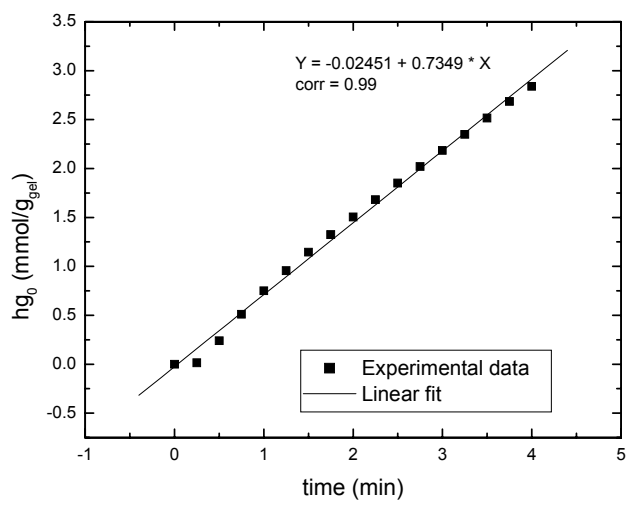

Figure 1: Determination of initial reaction rate of whey protein $(60 \mathrm{~g} / \mathrm{l})$ hydrolysis by alcalase immobilized on agarose gel particles at $\mathrm{pH} 10$ and $\mathrm{T}=50^{\circ} \mathrm{C}$.

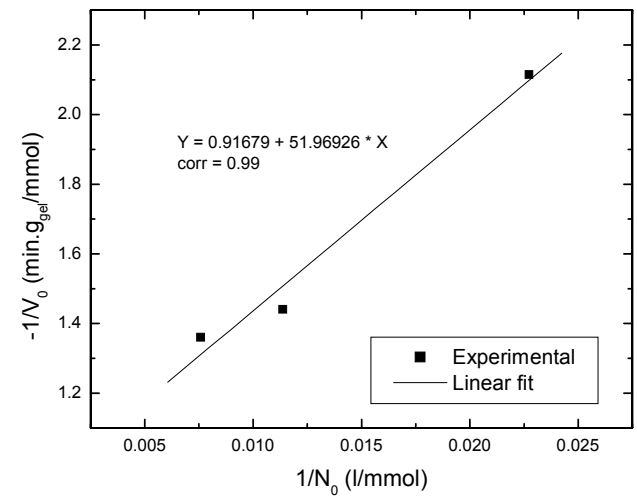

Figure 2: Lineweaver-Burk plot for whey protein hydrolysis by alcalase immobilized on agarose gel particles at $\mathrm{pH} 10$ and $\mathrm{T}=50^{\circ} \mathrm{C}$.

Table 2: Michaelis-Menten kinetic parameters $k$ and $K_{M}$; whey protein hydrolysis by alcalase immobilized on agarose gel particles; $\mathrm{T}=50^{\circ} \mathrm{C}$.

\begin{tabular}{|c|c|c|c|}
\hline $\mathbf{p H}$ & $\begin{array}{c}\mathbf{k . E} \\
\text { (mmol/gol } \mathbf{g i n})\end{array}$ & $\begin{array}{c}\mathbf{k} \\
\left.\mathbf{( m m o l} / \mathbf{U}_{\text {BAEE }} \mathbf{m i n}\right)\end{array}$ & $\begin{array}{c}\mathbf{K}_{\mathbf{M}} \\
(\mathbf{m m o l} / \mathbf{l})\end{array}$ \\
\hline $\mathbf{1 1}$ & 1.07 & 0.068 & 54.3 \\
$\mathbf{1 0}$ & 1.09 & 0.069 & 56.7 \\
$\mathbf{9}$ & 0.86 & 0.055 & 47.3 \\
$\mathbf{8}$ & 0.49 & 0.031 & 36.2 \\
$\mathbf{7}$ & 0.70 & 0.044 & 21.1 \\
$\mathbf{6}$ & 0.34 & 0.022 & 28.8 \\
\hline
\end{tabular}

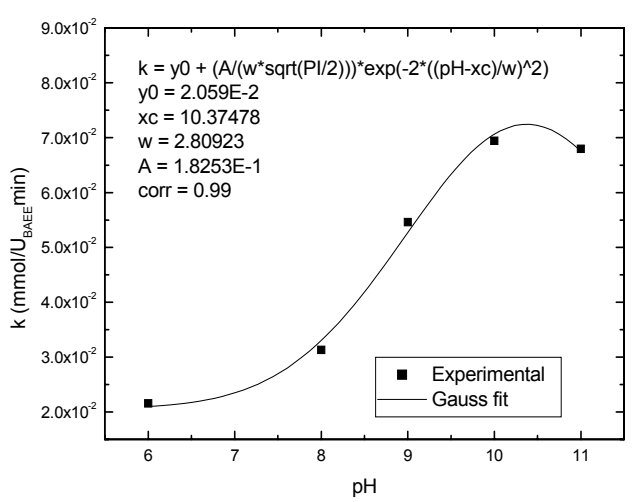

Figure 3: Influence of $\mathrm{pH}$ on the kinetic rate constant $(\mathrm{k})$ for whey protein hydrolysis by alcalase immobilized on agarose gel particles at $\mathrm{T}=50^{\circ} \mathrm{C}$. 


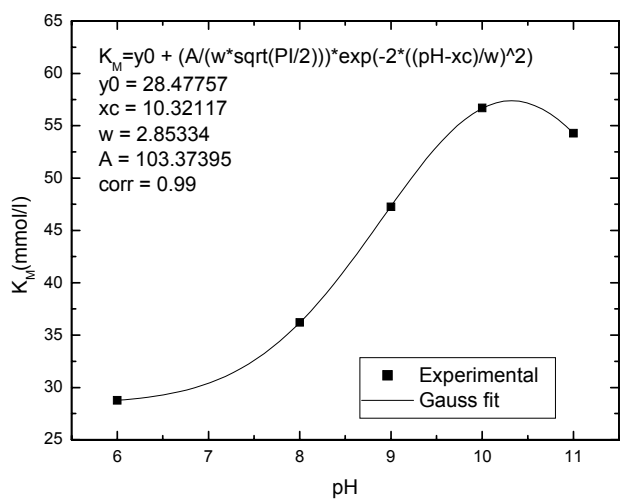

Figure 4: Influence of $\mathrm{pH}$ on the kinetic rate constant $\left(\mathrm{K}_{\mathrm{M}}\right)$ for whey protein hydrolysis by alcalase immobilized on agarose gel particles at $\mathrm{T}=50^{\circ} \mathrm{C}$.

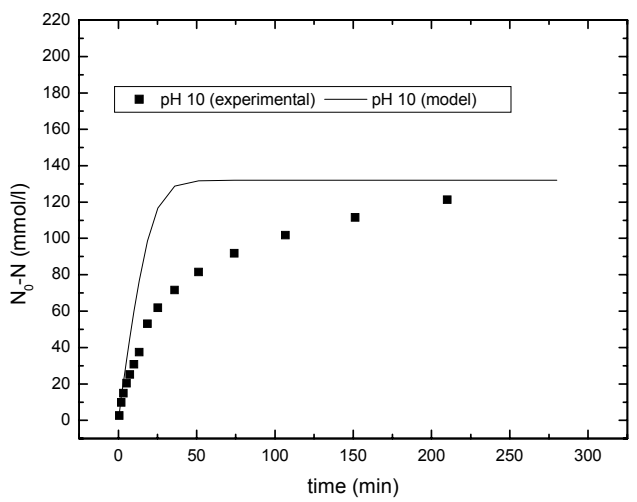

Figure 5: Michaelis-Menten model predictions (without inhibition) and experimental values for the number of hydrolyzed peptide bonds for whey protein hydrolysis by alcalase immobilized on agarose gel particles at $\mathrm{pH} 10$ and $\mathrm{T}=50^{\circ} \mathrm{C}$.

These data were used for adjusting $\mathrm{K}_{\mathrm{I}}$. During the fitting procedure, it was also possible to confirm the consistency of the values previously obtained for $\mathrm{K}_{\mathrm{M}}$ and $\mathrm{k}$. Table 3 shows the values of $\mathrm{K}_{\mathrm{I}}$ as a function of $\mathrm{pH}$. Each new acyl-terminal, produced after the hydrolysis of a peptide bond, may link to the enzyme active site (a serine), making a non-productive acylenzime complex. Therefore, $\mathrm{I}=\left(\mathrm{N}_{0}-\mathrm{N}\right)$.

Table 3: Inhibition parameter $K_{\mathrm{I}}$; whey protein hydrolysis by alcalase immobilized on agarose gel particles; $\mathbf{T}=50^{\circ} \mathrm{C}$.

\begin{tabular}{|c|c|}
\hline $\mathbf{p H}$ & $\mathbf{K}_{\mathbf{I}}(\mathbf{m m o l} / \mathbf{l})$ \\
\hline $\mathbf{1 0}$ & 7.0 \\
$\mathbf{9}$ & 4.0 \\
$\mathbf{8}$ & 1.2 \\
$\mathbf{7}$ & 0.8 \\
\hline
\end{tabular}

Graphically we have 


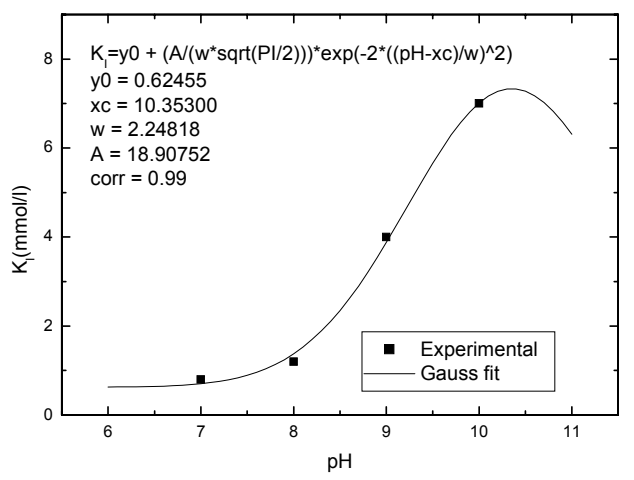

Figure 6: Influence of $\mathrm{pH}$ on the inhibition kinetic parameter $\left(\mathrm{K}_{\mathrm{I}}\right)$ for whey protein hydrolysis by alcalase immobilized on agarose gel particles at $\mathrm{T}=50^{\circ} \mathrm{C}$.

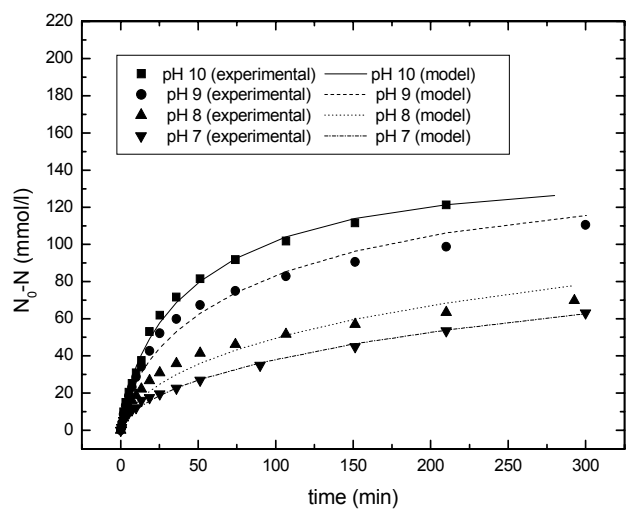

Figure 7: Michaelis-Menten model predictions (with inhibition) and experimental values for the number of hydrolyzed peptide bonds for whey protein hydrolysis

by alcalase immobilized on agarose gel particles at $\mathrm{pH} 10$ and $\mathrm{T}=50^{\circ} \mathrm{C}$.

Figure 7 shows the model predictions and the experimental values for the number of hydrolyzed peptide bonds for the long-term assays carried out in the pHstat.

It is possible to observe the very good agreement between model predictions and experimental data.

\section{CONCLUSIONS}

By making use of the pHstat technique and the Marquardt algorithm, it was possible to estimate kinetic parameters for the enzymatic proteolysis of cheese whey, using alcalase, multipoint-immobilized on agarose gel particles. A process of competition between the original substrate and the peptides that are continuously produced during the reaction brings about a substantial reduction in the reaction rates of proteolysis. Therefore, neither pure Michaelis-
Menten nor first-order kinetics could represent our data, although these are the two usual forms of rate equation proposed in the literature for enzymatic proteolysis. A kinetic model with product competitive inhibition, however, provided an accurate fit for our experimental data.

\section{ACKNOWLEDGEMENTS}

The authors acknowledge the support received from FAPESP, $\mathrm{CNPq}$ and $\mathrm{PADCT} / \mathrm{CNPq}$, Brazil. Cooperativa de Lacticínios de São Carlos (Brazil) kindly provided the cheese whey.

\section{NOMENCLATURE}

B base consumption (ml) 


\begin{tabular}{|c|c|}
\hline DH & degree of hydrolysis \\
\hline $\mathrm{E}$ & enzyme contents in the agarose gel \\
\hline$h_{\text {tot }}$ & $\begin{array}{l}\left(\mathrm{U}_{\mathrm{BAEE}} / \mathrm{g}_{\mathrm{gel}}\right) \\
\text { the total number of peptide bonds in the } \\
\left.\text { protein substrate (mmol } / \mathrm{g}_{\text {protein }}\right)\end{array}$ \\
\hline h & $\begin{array}{l}\text { the number of hydrolyzed peptide bonds } \\
\left(\mathrm{mmol} / \mathrm{g}_{\text {protein }}\right)\end{array}$ \\
\hline $\mathrm{hg}_{0}$ & $\begin{array}{l}\text { number of hydrolyzed peptide bonds per } \\
\text { gram of gel calculated for the first minutes } \\
\text { of reaction in the initial rate assays } \\
\left(\mathrm{mmol} / \mathrm{g}_{\mathrm{gel}}\right)\end{array}$ \\
\hline & molar concentration of inhibitor (mmol/l) \\
\hline $\mathrm{k}, \mathrm{K}_{\mathrm{M}}$ & kinetic model parameter and $\mathrm{K}_{\mathrm{I}}$ \\
\hline MP & mass of protein $(\mathrm{g})$ \\
\hline $\mathrm{N}$ & $\begin{array}{l}\text { molar concentration of peptide bonds in the } \\
\text { substrate hydrolyzable by alcalase }(\mathrm{mmol} / \mathrm{l})\end{array}$ \\
\hline $\mathrm{N}_{\mathrm{b}}$ & base normality \\
\hline & proteolysis reaction rate $\left(\mathrm{mmol} / \mathrm{g}_{\mathrm{gel}} \cdot \mathrm{min}\right)$ \\
\hline$\alpha$ & $\begin{array}{l}\text { the average degree of dissociation of } \alpha-\mathrm{NH} \\
\text { groups }\end{array}$ \\
\hline$\eta$ & $\begin{array}{l}\text { measured reaction rate/reaction rate in the } \\
\text { absence of mass transfer effects }\end{array}$ \\
\hline
\end{tabular}

\section{REFERENCES}

Adler-Nissen, J., Enzymic Hydrolysis of Food Proteins. Elsevier Applied Science Publishers (1986).

Demetrakakes, P., Waste Not, Want Not, Food Processing, July, 75-79 (1997).

González-Tello, P., Camacho, F., Jurado, E., Páez, M.P. and Guadix, E.M., Enzymatic Hydrolysis of Whey Proteins, Biotechnology and Bioengineering,
44, 523-528 (1994).

Lopes, G.P., Estudo do Controle do pH da Hidrólise Enzimática de Soro de Queijo. Master's thesis, Universidade Federal de São Carlos-São Paulo (2001).

Mann, E., Whey Products and Their Uses, Dairy Industries International, December, 13-14 (2000).

Marquardt, D.W., An Algorithm for Least-Squares Estimation of Nonlinear Parameters, J. Soc. Indust. Appl. Math., 11, 431-441 (1963).

Postolache, C. and Oncescu, T., Kinetics of Hemoglobin and Casein Hydrolysis Catalyzed by Alcalase, Revue Roumaine de Chimie, 34, 581-584 (1989).

Segel, I.H., Enzyme Kinetics. A Wiley-Interscience Publication (1975).

Svendsen, I., Chemical Modifications of the Subtilisins with Special Reference to the Binding of Large Substrates. A Review, Carlsberg Res. Commun., 41, 237-291 (1976).

Tardioli, P.W., Hidrólise Controlada de Proteínas do Soro Lático Usando Carboxipeptidase A e Agarose Imobilizadas Multipontualmente em Agarose. Ph.D Thesis, Universidade Federal de São Carlos-São Paulo (2003).

Viotto, W.H., Ultrafiltração de Soro Doce de Queijo Minas Frescal. Efeito de Pré-tratamento do Soro no Desempenho da Membrana de Ultrafiltração e na Composição e Solubilidade do Concentrado Protéico de Soro. Ph.D. Thesis, Universidade Estadual de Campinas-São Paulo (1993).

Vorob'ev, M.M., Levicheva, I.Y. and Belikov, V.M., Kinetics of the Initial Stage of Milk Protein Hydrolysis by Chymotrypsin, Applied Biochemistry and Microbiology, 32, 219-222 (1996). 